\title{
Conceptualizing Sex with Cerebral Palsy: A Phenomenological Exploration of Private Constructions of Sexuality Using Sexual Script Theory
}

\author{
Tinashe Moira Dune \\ Correspondence: Tinashe Moira Dune, University of Western Sydney, School of Science and Health, Campbelltown, \\ New South Wales, Australia
}

Received: November 21, 2013

Accepted: December 3, 2013 Available online: January 25, 2014

doi:10.11114/ijsss.v2i2.287

URL: http://dx.doi.org/10.11114/ijsss.v2i2.287

\begin{abstract}
This study explored how people with cerebral palsy (CP) negotiated and perceived their sexual interactions with others. In doing so, this research discusses participant conceptualizations of sexuality with CP. In-depth, semi-structured interviews were conducted with two women and five men with moderate to severe cerebral palsy from Canada and Australia. The interview discourse focused on how, if at all, private/internal constructions of sexuality influenced the way in which participants expressed and negotiated their sexuality. Interview data were thematically analyzed using NVivo and manual line-by-line analysis.

Notably, accepting oneself was important to people with cerebral palsy's sense of sexuality. By critically discounting exclusionary or negative sexual schema, people with cerebral palsy learn to be more accepting of their abilities and attribute positive conceptualizations to themselves and their sexual identity. Participants had mixed perceptions of body esteem as an aspect of their sexuality. Downward social comparisons were associated with positive body esteem. Negative body esteem could be an after effect of the lack of resources to support people with cerebral palsy in their sexual participation (i.e., sexual surrogates, workers, sexual facilitation from care providers, privacy or accessibility to transport) (see Earle, 1999). Participants also believed their sexual agency was constrained. For instance, they were apprehensive about explicitly asking for what they required from a sexual partner for fear that they may seem overly demanding, which could frustrate a sexual partner or end a relationship.

For people with CP personal agency yields more satisfying socio-sexual outcomes. The present study suggests that people with cerebral palsy do in fact recognize that being sexually agential would increase their sense of sexual satisfaction and empowerment. Further, participants believed that sexual agency could be enhanced with personal effort. In this regard, the ability to make (and exercise) choice when negotiating sexuality reinforces conceptualizations of oneself as a sexually desirable being.
\end{abstract}

Keywords: cerebral palsy, sexual script theory, sexuality, disability, Australia, Canada, sexual agency

\section{Introduction}

Constructions of sexuality by people with cerebral palsy are partly informed, by a range of public, interactional and private factors (Simon \& Gagnon, 1986, 1987, 2003). Whilst interactional constructions of sexuality are influenced and reinforced by public attitudes and interpretations it is the private and therefore most personal aspects of sexuality which drives the ability to perceive oneself as a sexual being, understanding one's own sexual desires and dictates one's propensity to on those sexual inclinations. People with physical disability are no different - except in the fact that their ability and/or willingness to make overtures towards interactional sexual experiences may not be facilitated and/or welcome.

People with disabilities and typical others may internalize sexual scripts which do not account for variance in the human condition. Without a framework which allows people with impairment to express their thoughts, feelings and desires their socio-sexual experience(s) may not be acknowledged (Blakar \& Nafstad, 2006; Gould, 2009; Faulkman et al., 2005; McCormack et al., 2010). As such, some private constructions of disability and sexuality may be based on misunderstanding about how atypical others experience or want to experience their sexuality. Subsequently typical and atypical others may privatize misleading information or attitudes about sexuality in people with disabilities. The 
privatization of exclusionist public and interactional scripts of sexuality has played a significant role in how people with disabilities construct their (sexual) identity (Guildin, 2000).

Open discourse about the private factors which influence constructions of sexuality for people with disabilities brings awareness of the barriers which may reduce sexual self-identification and esteem. In doing so, sexual expression, pleasure, intimacy and ultimately satisfaction are acknowledged as essential to the formation of private constructions of sexuality for people with disability. As such, this paper qualitatively explores private factors and private sexual schema which may influence contemporary constructions of sexuality and disability for people with cerebral palsy.

\subsection{Private Factors}

Constructions of sexuality can be created through private mental processes which involve inner dialogue (Emerson, 1983). These private mental processes can influence the way individuals internalize sexual scripts and consolidate perceptions and constructions of sexuality. Simon and Gagnon (1986) noted that private sexual scripts are "the symbolic reorganization of reality in ways that makes it complicit in realizing more fully the actor's many-layered and sometimes multicoated wishes" (p. 99).

Privatizations of sexual expectations, behaviour and constructions are bound to public and interpersonal social scripts (Kant, 1958). In this regard, the ways in which people think about disability is linked to how it is publically represented (i.e., mass media) and how people with disabilities experience in interactional encounters (i.e., intimate relationships). As such, this section begins with a brief discussion of the role private influences play in the construction of sexuality for people with disabilities. This will be followed by an analysis of the following private influences and their salience to private constructions of sexuality:

- disability and sexual identity

- sexual agency

- constructions of sexual self:

○ body image and body esteem,

$\circ$ sexual esteem

$\circ \quad$ sexual desirability

\subsubsection{Disability and Sexual Identity}

People with disabilities may construct their identity through the experiences they have had with impairment and the experiences others have had with disability (see Shakespeare, 1996). It has been suggested however, that this view of identity may lack holistic elements. Giddens (1991) for example, explains that "self-identity is not a distinctive trait, or even a collection of traits, possessed by the individual. A person's identity is not to be found in behaviour nor important though this is - in the reaction of others, but in the capacity to keep a particular narrative going" (p. 53). In this way identity is created through the complex interplay between the heterogeneous influence of the public, the interactional and the private to create a homogeneous self. For instance, through the context of GLBTQ (Gay, Lesbian Bisexual, Transgender or Queer) advocacy Weeks (1977) suggested that the concept of identity is akin to finding a map to explore a new country. These understandings of identity attract attention to positive identity narratives about disability which are created by the individual themselves. As such, disability as part of one's identity may not be intrinsically negative. The experience of disability as a negative identity arises out of a process of socialization.

Shakespeare (1996) discussed the social contention experienced due to assumptions made about what he called "disabled identity." Shakespeare uses a quote by Morris (1991) to explain that the identity of the person with a disability in relation to those around them influences how they will interact with others:

One of the most important features of our experience of prejudice is that we generally experience it as isolated individuals. Many of us spend most of our lives in the company of non-disabled people, whether in our families, with friends, in the workplace, at school and so on. Most of the people we have dealings with, including our most intimate relationships, are not like us. It is therefore very difficult for us to recognize and challenge the values and judgments that are applied to us and our lives. Our ideas about disability and about ourselves are generally formed by those who are not disabled.' (p. 37)

In this way negative constructions of the "disabled identity" may reinforce the stigmatization of people with disabilities. According to Shakespeare the disabled identity does not need to be constructed negatively if societies are given opportunities to discuss, listen and understand experiences of disability or impairment. In doing so, people with disabilities can actively participate in discourse which they are directly and indirectly involved. In doing so impairment and disability can be discussed openly thereby addresses myths, misconceptions, and barriers as well as acknowledge 
similarities between people with and without disabilities and the facilitators which improve social and sexual acceptance and integration.

Public, interactional and private representations (or the lack thereof) of how people with physical disability experience their sexuality has a multitude of implications for the private formulation of their sexual identity (Cheng \& Udry, 2002; Murphy, Molnar \& Lankasky, 2000; Rurangirwa, Braun, Schendel \& Yeargin-Allsopp, 2006). While contemporary societies work through the process of socio-sexual acclimatization to difference, some people with disabilities may feel inclined to downplay or separate the effect of impairment from their construction of their sexual identity. Overstreet (2008) analysed the disability/sexuality split exhibited by Texas Rose, a female porn-star with a physical disability and whose primary form of movement was her wheelchair. Overstreet investigated the presence of visible markers of disability and sexual imagery on Texas Rose's website. In the majority of the photos analyzed there was no sign of Texas Rose's wheelchair. In addition Overstreet classified the types of sexual activities depicted when Texas Rose was in her wheelchair as tame which consisted of her posing, undressing, and blowing kisses.

When the wheelchair was partially or fully pictured but she is not sitting in it her actions consisted of applying sunscreen, blowing kisses, and holding her thong down to show her genitals. However, when her wheelchair was not pictured her actions were more sexual. These pictures showed her touching her breast, touching her hair and shoulder, mutual petting/she and another woman touching each other's' arms, another woman using a tasseled whip to tickle Texas Rose's leg and holding her knee tied with a stocking, and Texas Rose holding and licking another woman's nipple. Portraying sexual activity as separate from disability is problematic. This research implies that sexual activity may be perceived by some viewers of pornography as unsexy when paired with disability or indicators of physical impairment. Consequently, people may privatize conditional portrayals of sexual activity, expression, pleasure and satisfaction. The conditionality of normalized constructions of sexuality may mean that someone with a disability may be perceived as sexier if they separate the indicators of difference from their sexual identity. However this type of restriction on individual constructions of sexual identity may impair one's ability to exercise choice and control over sexual experiences (McCormack et al., 2010).

\subsubsection{Sexual Agency}

As defined by the World Health Organization (2011) sexual agency is a basic sexual right and includes "the right to have one's bodily integrity respected and the right to choose - to choose whether or not to be sexually active, to choose one's sexual partners, to choose to enter into consensual sexual relationships, and to decide whether or not, and when, to have children" (Parker, 2007, p. 973). Froyum (2009) suggests that sexual agency as not only the right to choose but also to seek knowledge and assert sexual desires. In addition, Wilkerson (2002) argues that sexual agency is not merely the capacity to choose, engage in, or refusesex acts, but is a more profound good which involves alarger social dimension in which others recognize and respect one's identity. Wilkerson's conceptualization of sexual agency expresses the interdependence of public, interactional and private experiences of sexual expression and behaviour. In this way, Wilkerson demonstrates the importance of sexual agency, a key component of the liberation struggles of all disenfranchised groups, rather than a luxury for those who are categorized as typical or something that can be addressed afterachieving goals that might be perceived as more basic. This is particularly important in rehabilitative contexts for people with physical disabilities.

Wilkerson (2002) described many instances in which medical discourse, often in the veryliteral form of a doctor's words, denied the sexuality of people with disabilities. Three instances she reports include: A man and a woman who had spent years livingin an institution for people with epilepsy wanted to marry, and requested permissionof a doctor at the institution. They were told "that they could get married, but they were not allowed to have sex" (p. 48). She also reports an instance in which aparaplegic woman was denied her oral contraceptives by her doctor: "about four days after I broke my back I asked my surgeon, 'I don't have my birth controlpills with me. Is there something I can do about that?' He said 'Well, you don't needthose anymore,' and walked out of my room” (p. 34). Wilkerson also tells of the abuse ofa young boy with an intellectual disability: a young man living in an institution masturbated in the presence of others "by rubbing his thighs together when sitting down. So the staff at the institution attached sandpaper to the insides of his thighs" (p. 34).In each of these instances the relationship between disability, sexual identity and agency, are determined and controlled by healthcare providers. Considering the influence of public and interactional factors on sexual agency people with disabilities may experience a sense of powerlessness. Particularly, interference with the sexual agency of an individual caused by unnecessary or unfair restrictions, penalties, and coercion, denies people with disabilities access to important information about their sexual rights and the discovery and exploration of their sexuality.

Portrayals of positive sexual identity, agency and disability are being represented. Abbott (2010) drew on theory, literature and art to explore representations of embodiment that are produced at the intersections of queer studies and disability studies. According to Abbott the acknowledgement of different manifestations of the human body as sexual is being realized through the Arts. For example, performance artist Flanagan and performance collective Sins Invalid 
create theatrical representations of the intersection of disability and sexuality. In their performances,these artists assert the experiences of "queer" and "disabled bodies" as sites of knowledge, agency, exploration, respect and pleasure. Abbott (2010) notes that by "embracing vulnerability andinterdependence, by imbuing the individual with the agency to re-imagine the socially producedbody, and by rooting these struggles in community, the work of these artists fiercely locate liberatory struggle in the body" (p. 12). This is to say that people with physical disabilities may have to struggle to integrate experiences of disability into their experiences of sexuality and experiences of sexuality into their experiences of disability. In doing so, these individuals can create a sexuality which holistically reflects their thoughts, feelings, choices, desires and actions.

\subsubsection{Constructions of Sexual Self}

The consolidation of sexual identity and its place in relation to the sexual identity of others is mediated by public, interactional and private influences. It may be however that people with disabilities may construct their sexual selves (and perhaps their sexuality) differently than prescribed or expected. In this way sexuality for atypical populations may not exist as a script in which one must play a role but as an individual creation which is asserted, experienced, developed and negotiated through oneself and, potentially, others. However, due to the prevalence of hegemonic sexual schemas people with disabilities may experience barriers when attempting to privatize their experiences of sexuality in relation to others. The contention some people with disabilities may experience due to the differences between popular constructions of sexuality and their own may have a detrimental effect on their ability to privatize a positive sense of sexual self. As the body is perhaps the most apparent basis upon which humans interpret and judge another the privatization of conceptualizations of one's body is important to constructions of one's sexual self.

\subsubsection{Body image and Body Esteem}

Body image is an important factor in how humans conceive of themselves physically and is an integral part in the conception of sexual self (Grogan, 2008). Taleporos and McCabe (2002) defined body image "as the combination of an individual's psychological experiences, feelings and attitudes that relate to the form, function, appearance and desirability of one's own body which is influenced by individual and environmental factors" (p. 971). Further, body esteem refers to the perceptions an individual has about their own body (Taleporos \& McCabe, 2002). Moreover, these perceptions are linked to and influenced by an individual's identity, body image and experiences.

The perceptions people with disabilities have about their bodies may be built on previous experiences and opportunities to develop or participate in intimate relationships. As such, feedback from the social environment is a powerful mediator of body esteem among people with physical disabilities (Palombi \& Mundt, 2006). Quantitative research by Lease et al. (2007) investigated whether body and sexual esteem mediated the associations between sexual satisfaction, perceived severity of the disability, and social perceptions of the disability and interpersonal competencies. The data from 326 web-based questionnaires indicated that sexual satisfaction, social perceptions of the disability, and perceived severity of the disability significantly predicted competence with relationship initiation for the male participants. For men, higher levels of sexual satisfaction and social perceptions of their disability predicted competence with negative assertion (i.e., disagreeing with one's partner). Social perceptions of disability predicted both interpersonal competencies, and sexual satisfaction for the female participants. Lease et al. explained that these results demonstrated that participants' perceptions of their disability were mediated by their perception of their sexual attractiveness to others. As such, negative social attitudes about disability or physical impairment were unlikely to nurture the development of positive perceptions of one's body. Alternatively, Lease et al. indicated that positive social and sexual feedback can provide the basis for adjustment and acceptance of one's body and supports the formation of positive body image (see also Piotrowski \& Snell, 2007).

The implications of a positive or negative sense of one's body can be expansive. Considering that sexual expectations, like physical perfection, may complicate perceptions of body image and esteem, people with (physical) disabilities may experience problems with depression and self-esteem related to concerns about their bodies, their sexual selves and their sexual lives (Esmail, Darry, Walter \& Knupp, 2010; Moin, Duvdevany \& Mazor, 2009; Sheilds, Murdoch, Loy, Dodds \& Taylor, 2006). In fact, body esteem and sexual well-being are more closely associated with overall psychological well-being for people with a physical disability than for typical others (Taleporos \& McCabe, 2002; Taylor \& Davis, 2007).

Physical impairment may have an impact upon the psychological experiences, feelings and attitudes people with physical disabilities have towards their own bodies. For example, Taleporos and McCabe (2002) quantitatively examined the relationship between sexuality and psychological well-being among people with physical disabilities compared to typical others. Taleporos and McCabe found that sexual esteem, body esteem, and sexual satisfaction were strong predictors of self-esteem and depression among people with physical disability. In addition, this relationship was stronger for people with physical impairment than amongst their typical peers. Specifically the authors indicated that 
negative attitudes towards disability and physical difference made it difficult for people with disabilities to think of themselves positively. These results imply that at some point in the lives of participants with a disability, body image had been a serious struggle as negative social attitudes towards physical difference were privatized (see also Shuttleworth, 2000). They also found that body esteem was more closely associatedwith self-esteem for women with disabilities, while sexual esteem was more closely associated with self-esteem in men with disabilities. Taleporos and McCabe concluded that researchers and healthcare practitioners concerned with the psychological well-being of people with physical impairments should consider strategies to improve the body esteem and sexual well-being of people within this group. If feelings of physical or sexual inadequacy are left to fester some people with disabilities may become more prone to abuse or assault then their peers who have been provided with readily accessible resources to cope with the psychological impact of disability.

\subsubsection{Sexual Esteem}

Another facet of the sexual self is sexual esteem. According to Hassouneh-Phillips and McNeff (2005) sexual esteem "refers to one's sense of self as a sexual being, ranging from sexually appealing to unappealing and sexually competent to incompetent" (p. 228). As sexual esteem is a factor which is influenced by perceptions of sexual identity Hassouneh-Phillips and McNeff suggest that perceiving oneself as a sexual being who is deserving of sexual attention can make a difference in regards to feelings about one's sexual worth.

However, the perceived impact impairment has on the sexuality of a person with a disability varies subjectively. While some people with disabilities feel as though impairment and their sexuality are not necessarily linked (Jemtå et al., 2008) others feel that impairment interferes with their substantive ability to perform sexually and subsequently provide sexual pleasure to themselves and their partner(s) (Kolotkin, Binks, Crosby, Østbye, Gress \& Adams, 2006). Guldin (2000) asserts that as so much of our sexual value is based on what we can do for our partner(s) and how well we can satisfy them, sexual esteem increases when we can show our partner(s) a "good time". Guldin's research is important to the discussion on sexual esteem as it explored how people with mobility impairments "self-interpret and self-claim their sexuality in light of cultural assumptions which largely desexualize them" (p. 233). In her study of 7 participants, Guldin reported on one of her participants' experiences of sexual satisfaction through pleasuring his partner:

[Marv] believes that the tongue can elicit more pleasure from a woman than the penis and he considers his tongue to be more finely tuned than the tongues of non-disabled men who, according to Marv, only perform oral sex so the act will be reciprocated. (p. 236)

Guldin's data indicates that sexual satisfaction can be experienced in many and different ways. Her research reinforces that there are plenty of activities that people can engage in that are sexually arousing and satisfying without necessarily including penetrative sex.

Moreover, this group experienced high levels of sexual esteem and believed their creativity provided their sexual partners with a different and more sensual type of sexual satisfaction. Guildin explains that some of the participants in her research took more time with their partners and felt that this made them more thorough lovers which they viewed as more sexually rewarding in relation than experiences of sexuality characterized by sexual scripts based on typical others. Guildin suggests that:

This inversion of ability/disability, physically non-disabled men become sexually disabled by their lack of sexual skill and sexual introspection. This "sexual disabling" of bodies that are-according to cultural definitions - functional, challenges notions not only of the "sexual body" and "sexuality" but also of what it means to be "disabled." (p. 236)

Although there is variability in regards to how positive people feel about their sexuality, many people with physical disabilities feel that having a disability does not necessarily make them any less "sexy" than their typical peers (Guildan, 2000; Quinlan \& Bates, 2008).

\subsubsection{Sexual Desirability}

Popular constructions of disability and sexuality which represent people with disabilities as sexually desirable mates are scarce. In their theoretical paper Glass and Padrone (1978) explain that "illness and disability remove the patient from accustomed personal, social, and sexual interactions, changing the entire life pattern . . . Feelings of self-worth and attractiveness are threatened at a time when need for intimacy and belonging is greatest, causing a sense of loneliness and isolation" (p. 42). Glass and Padrone acknowledged that positive experiences of sexuality and perceptions of sexual self were undermined by attitudes and assumptions which resulted from a lack of information experienced by people with disabilities as well as the various disciplines that serve them (i.e. medical, psychological and palliative).Participants in Murray and Harrison's (2004) qualitative research, which explored the meaning and experience of being a stroke survivor, reported multiple disruptions in social interactions and believed themselves to be 
sexually undesirable and less likely to be chosen as a romantic partner than someone who did not have a visible disability. This is often due to the barriers to inclusion they experience when trying to fulfill the requirements of normative sex roles and hegemonic sexual expectations (Kaufman et al., 2008; Murray \& Harrison, 2004).

Rintala et al. (1997) found that women with physical disabilities had self-defeating attitudes about their disabilities and ultimately themselves. Rintala and colleagues' (1997) quantitative research explored the dating issues women with physical disabilities face. They found that external discouragement of sexual activity and behaviour lowered the women's sense of sexual desirability. Participants of the Rintala et al. study expressed that when negotiating intimacy mutual attraction and flirting proceed normally until the potential partner realized they had a disability and suddenly changed their behaviour and they appeared to have lost interest. As such, some woman in their research devalued anyone who chose to date them and had internalized the societal belief that in choosing them, the other individual must have something wrong with them and are 'damaged goods' as well (see also Phillips, 1990). As some people with physical disabilities feel that their disability is what restricts them from being thought of as a potential sexual partner some begin to socially invert. Due (1995) explains that "many people with disabilities fear they'll be screened out before they can even say hello. "Some figure they'll not even try - and not trying can become a lifestyle" (p. 5D). The mixture of how people with disabilities perceive themselves and how they are perceived by others has a definitive effect on their ability to negotiate and access satisfying sexual relationships.

\subsection{Private Sexual Scripts and Cerebral Palsy}

The literature indicates that disability and impairment have a distinctive effect on the formation of sexual identity and the implementation of sexual agency. In this regard, disability literature is in line with the goals of this paper which presents the results of an exploration of how people with disabilities construct their own sexuality through an inquiry of their sexual identity and sexual experiences. The main difference between previous academic explorations of the factors which influence private constructions of sexuality in people with disabilities is that this study was particularly focused on people with cerebral palsy who are an understudied group.

In addition, contemporary literature which analyzed the effect private influences (i.e. perceptions of body image and body esteem, sexual esteem and perceptions of sexual desirability) have on disability reflects to goals of this study. Through the collection and analysis of data about the effect personal and private factors have on individual constructions of sexuality this paper aims to contribute to contemporary understandings of sexuality for people with Cerebral Palsy and ultimately people with disabilities.

\section{Methods}

This paper presents an excerpt of results from a doctoral project which used a hermeneutic phenomenological approach to explore the salience of sexual scripts (public, interactional and private) in constructions of sexuality by people with Cerebral Palsy. In-depth interviews were conducted with duration of one to two and a half hours.A semi-structured interview guide was used for data collection and comprised of the following sections: demographics and severity of disability, private sexual scripts, interactional sexual scripts, public sexual scripts and reflective summary. Interviews were conducted via email, telephone and/or face-to-face (based on participant preference).

In the private sexual scripts section of the interview participants were asked questions about the influence of private sexual scripts on constructions of sexuality for people with cerebral palsy this section was aimed at allowing participants to express private sexual feelings, thoughts and fantasies. The questions in this portion of the main study interview guide aimed to allow participants to express any private sexual schemas which act as a significant factor in personal mental processes and inner dialogues. Questions asked examined early sexual thoughts (i.e., "Can you please describe your early sexual thoughts or feelings to me?"), how participants would describe themselves and what they thought made them sexual and/or desirable (i.e., "What do you find sexy about yourself?"). These questions precluded the interactional section of the interview as they provided information about individual internalizations of sexuality.

The data were analyzed for content by identifying topics and substantive categories within participants' accounts in relation to the study's objectives. In addition, NVivo 9 was used to ascertain topical responses and emergent substantive categories, coding particularly for word repetition, direct and emotional statements and discourse markers including intensifiers, connectives and evaluative clauses. Due to the rich and contextual nature of the data, participant's responses have been presented in their conceptual entirety.

\section{Participant Recruitment}

This study included seven participants; five men and two women. Four of the participants were from Australia and three from Canada (see Table 1). The study recruited from Canada and Australia in order to enhance the possibility of finding members of the target population to participate.

In Australia, participants were recruited through advertisements published in community newspapers, bulletins, through 
advocacy group and sexuality and/or disability focused newsletters and webpages. In addition, the snowballing technique was carried out at the end of participant interviews and required asking each participant if they knew someone who met the eligibility criteria and, if so, whether s/he would be willing to give that person a copy of the participant information sheet. The author did not know the identity of this person, and the interviewee did not know if that person agreed to participate in the project or not.

In Canada, participants were sought through the Attendant Care Program in Ottawa, Ontario, Canada. The Attendant Care Program services two of the major educational institutions in the city with round-the-clock provision of personal care for tertiary students with disabilities who live in the university residence buildings. The program which has been running for over 20 years services approximately 50-60 students per year with numbers increasing every year. Due to the client-directed style of the program clients are provided with the resources they need to live independently through the provision of dignity-focused care and accessible living arrangements. As the author was formerly employed by the service she forwarded the coordinator of the program the details of this project and was informally given permission to ask clients (the majority of whom had Cerebral Palsy) of the Attendant Care Program if they would like to participate.

Table 1. Participant Summary

\begin{tabular}{|c|c|c|c|c|c|c|c|}
\hline $\begin{array}{l}\text { Participant } \\
\text { (Pseudonym) }\end{array}$ & Sex & $\begin{array}{l}\text { Type of } \\
\text { Cerebral } \\
\text { Palsy }\end{array}$ & $\begin{array}{l}\text { Assistive } \\
\text { Devices or } \\
\text { Services }\end{array}$ & $\begin{array}{l}\text { Socio-economic } \\
\text { Status, } \\
\text { education and } \\
\text { ethnicity }\end{array}$ & $\begin{array}{l}\text { Medical } \\
\text { Interventions }\end{array}$ & $\begin{array}{l}\text { Living } \\
\text { Arrangements }\end{array}$ & Sexual Profile \\
\hline John & Male & $\begin{array}{l}\text { Spastic } \\
\text { Quadriplegic } \\
\text { Cerebral } \\
\text { Palsy } \\
\text { (severe) }\end{array}$ & $\begin{array}{l}\text { Mechanized } \\
\text { wheelchair, } \\
\text { daily } \\
\text { personal } \\
\text { assistance } \\
\text { from others }\end{array}$ & $\begin{array}{l}\text { Upper-middle } \\
\text { class, tertiary } \\
\text { education, } \\
\text { Caucasian } \\
\text { Australian }\end{array}$ & $\begin{array}{l}\text { Major } \\
\text { musculoskeletal } \\
\text { surgery during } \\
\text { childhood and } \\
\text { adolescence. } \\
\text { Rehabilitative } \\
\text { maintenance. }\end{array}$ & $\begin{array}{l}\text { Lived with his } \\
\text { mother in his } \\
\text { family's home }\end{array}$ & $\begin{array}{l}\text { Heterosexual, } \\
\text { sexually active, } \\
\text { no history of } \\
\text { long term } \\
\text { sexually } \\
\text { intimate } \\
\text { relationships }\end{array}$ \\
\hline Mary & Female & $\begin{array}{l}\text { Spastic } \\
\text { Paraplegic } \\
\text { Cerebral } \\
\text { Palsy } \\
\text { (moderate) }\end{array}$ & $\begin{array}{l}\text { Occasional } \\
\text { use of } \\
\text { crutches }\end{array}$ & $\begin{array}{l}\text { Middle class, } \\
\text { tertiary } \\
\text { education, } \\
\text { Caucasian } \\
\text { Australian }\end{array}$ & $\begin{array}{l}\text { Major } \\
\text { musculoskeletal } \\
\text { surgery during } \\
\text { childhood and } \\
\text { adolescence. } \\
\text { Rehabilitative } \\
\text { maintenance. }\end{array}$ & $\begin{array}{l}\text { Lived } \\
\text { independently } \\
\text { in an apartment } \\
\text { with her partner }\end{array}$ & $\begin{array}{l}\text { Heterosexual, } \\
\text { in a long term } \\
\text { sexual } \\
\text { relationship at } \\
\text { time of } \\
\text { interview }\end{array}$ \\
\hline Brian & Male & $\begin{array}{l}\text { Ataxic } \\
\text { Quadriplegic } \\
\text { Cerebral } \\
\text { Palsy } \\
\text { (severe) }\end{array}$ & $\begin{array}{l}\text { Mechanized } \\
\text { wheelchair, } \\
\text { daily } \\
\text { personal } \\
\text { assistance } \\
\text { from others }\end{array}$ & $\begin{array}{l}\text { Middle class, } \\
\text { tertiary } \\
\text { education, } \\
\text { Caucasian } \\
\text { Australian }\end{array}$ & $\begin{array}{l}\text { Major } \\
\text { musculoskeletal } \\
\text { surgery during } \\
\text { childhood and } \\
\text { adolescence. } \\
\text { Rehabilitative } \\
\text { maintenance. }\end{array}$ & $\begin{array}{l}\text { Lived in an } \\
\text { independent } \\
\text { living facility }\end{array}$ & $\begin{array}{l}\text { Heterosexual, } \\
\text { sexually active, } \\
\text { no history of } \\
\text { long term } \\
\text { sexually } \\
\text { intimate } \\
\text { relationships }\end{array}$ \\
\hline Leah & Female & $\begin{array}{l}\text { Spastic } \\
\text { Paraplegic } \\
\text { Cerebral } \\
\text { Palsy } \\
\text { (moderate) }\end{array}$ & $\begin{array}{l}\text { Mechanized } \\
\text { wheelchair, } \\
\text { daily } \\
\text { personal } \\
\text { assistance } \\
\text { from others }\end{array}$ & $\begin{array}{l}\text { Lower-middle } \\
\text { class, tertiary } \\
\text { education, } \\
\text { Caucasian } \\
\text { Australian }\end{array}$ & $\begin{array}{l}\text { Major } \\
\text { musculoskeletal } \\
\text { surgery during } \\
\text { childhood and } \\
\text { adolescence. } \\
\text { Rehabilitative } \\
\text { maintenance. }\end{array}$ & $\begin{array}{l}\text { Lived in an } \\
\text { apartment with } \\
\text { her boyfriend. }\end{array}$ & $\begin{array}{l}\text { Heterosexual, } \\
\text { in a long term } \\
\text { sexual } \\
\text { relationship at } \\
\text { time of } \\
\text { interview }\end{array}$ \\
\hline Ian & Male & $\begin{array}{l}\text { Ataxic } \\
\text { Quadriplegic } \\
\text { Cerebral } \\
\text { Palsy } \\
\text { (severe) }\end{array}$ & $\begin{array}{l}\text { Mechanized } \\
\text { wheelchair, } \\
\text { daily } \\
\text { personal } \\
\text { assistance } \\
\text { from others }\end{array}$ & $\begin{array}{l}\text { Lower-middle } \\
\text { class, tertiary } \\
\text { education, } \\
\text { Caucasian } \\
\text { Canadian }\end{array}$ & $\begin{array}{l}\text { Major } \\
\text { musculoskeletal } \\
\text { surgery during } \\
\text { childhood and } \\
\text { adolescence. } \\
\text { Rehabilitative } \\
\text { maintenance. }\end{array}$ & $\begin{array}{l}\text { Lived in an } \\
\text { independent } \\
\text { living facility. }\end{array}$ & $\begin{array}{l}\text { Heterosexual, } \\
\text { sexually active, } \\
\text { no history of } \\
\text { long term } \\
\text { sexually } \\
\text { intimate } \\
\text { relationships }\end{array}$ \\
\hline Trevor & Male & Spastic & Mechanized & Upper-middle & Major & Lived in an & Heterosexual, \\
\hline
\end{tabular}




\begin{tabular}{|l|l|l|l|l|l|l|l|}
\hline & & $\begin{array}{l}\text { Quadriplegic } \\
\text { Cerebral } \\
\text { Palsy } \\
\text { (severe) }\end{array}$ & $\begin{array}{l}\text { wheelchair, } \\
\text { daily } \\
\text { personal } \\
\text { assistance } \\
\text { from others }\end{array}$ & $\begin{array}{l}\text { class, tertiary } \\
\text { education, } \\
\text { Caucasian } \\
\text { Canadian }\end{array}$ & $\begin{array}{l}\text { musculoskeletal } \\
\text { surgery during } \\
\text { childhood and } \\
\text { adolescence. } \\
\text { Rehabilitative } \\
\text { maintenance. }\end{array}$ & $\begin{array}{l}\text { independent } \\
\text { living facility }\end{array}$ & $\begin{array}{l}\text { in a long term } \\
\text { sexually } \\
\text { intimate } \\
\text { relationship at } \\
\text { time of the } \\
\text { interview }\end{array}$ \\
\hline Alex & Male & $\begin{array}{l}\text { Quadriplegic } \\
\text { Cerebral } \\
\text { Palsy } \\
\text { (severe) }\end{array}$ & $\begin{array}{l}\text { Mechanized } \\
\text { wheelchair, } \\
\text { daily } \\
\text { personal } \\
\text { assistance } \\
\text { from others }\end{array}$ & $\begin{array}{l}\text { Upper-middle } \\
\text { class, tertiary } \\
\text { education, } \\
\text { Caucasian } \\
\text { Canadian }\end{array}$ & $\begin{array}{l}\text { Major } \\
\text { musculoskeletal } \\
\text { surgery during } \\
\text { childhood and } \\
\text { adolescence. } \\
\text { Rehabilitative } \\
\text { maintenance. }\end{array}$ & $\begin{array}{l}\text { Lived in an } \\
\text { independent } \\
\text { living facility } \\
\text { high frequency } \\
\text { of casual sexual } \\
\text { encounters, no } \\
\text { history of long } \\
\text { term sexually } \\
\text { intimate } \\
\text { relationships }\end{array}$ \\
\hline
\end{tabular}

\section{Results and Discussion}

Private sexual schema was the least influential factor (compared to public and interactional schema) in the construction of sexuality by people with cerebral palsy. Five major themes were identified within participant data in regards to private sexual schema which will be presented and discussed as follows: 1) The Intersection between Disability and Sexual Identity, 2) Perceptions of Sexual Desirability, 3) Body Esteem, 4) Sexual Agency and, 5) Sexual Esteem.

\subsection{The Intersection between Disability and Sexual Identity}

Personal experiences of disability and perceptions of sexual identity was of relatively moderate importance to participants overall construction of their sexuality. Participants also expressed that harmonizing their personal care needs with their sexual needs was imperative to satisfactory experiences of their sexuality. Finally, respondents mentioned that being comfortable with themselves and their sexuality was important to cultivating a positive construction of their sexuality.

The theme Intersection between Disability and Sexual Identity yielded three sub-themes (see Figure 1): Reconciling Disability and Sexuality, Harmonizing Care Needs and Sexual Needs and The Importance of Accepting Oneself.

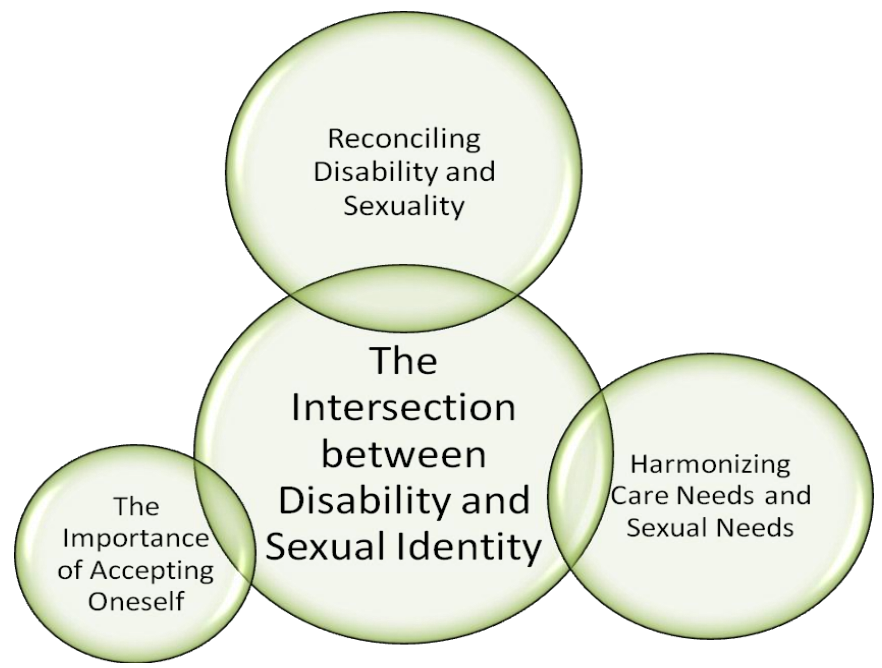

Figure 1 . The Intersection between Disability and Sexual Identity Theme and Sub-themes

\subsubsection{Reconciling Disability and Sexuality}

Participants believed that a concerted effort needed to be made in order to privately reconcile their identity as an individual living with a disability and their sexual identity (Kaufman, 2010). However, they also believed that sexuality and disability were best dealt with separately (Cheng \& Udry, 2002). For example, Alex explained that some of the most important transitions in his life revolved around consolidating his sexual and "disabled" identity.

Alex: Obviously my coming out of the closet was a very important transition in my life. However, I also 
think that I had to come out twice: as gay and disabled. That happened when I starting meeting sexual partners. It was at that point that I truly understood the impact of my disability.

Brian felt that the most obvious influence on the way he privatized his sexuality was living with a severe physical disability.

Brian: The most obvious one that jumps out at me is my disability. Being limited to the use of two fingers on my left hand and limited vocal ability has definitely influenced the way that I perceive my sexuality and the way my sexuality is perceived by others. My personality is another key factor, as I have never been one to hide my disability and have always been very strong on my identity as an individual with a physical disability.

Brian indicated that disability is an integral factor in the way they he perceives his sexuality and his identity: "Being limited... definitely influenced the way that I perceive my sexuality and the way my sexuality is perceived by others." Living with a moderate to severe disability was indicated by all participants as a factor they needed to negotiate privately in order to satisfactorily experience their sexuality: "I have never been one to hide my disability and have always been very strong on my identity as an individual with a physical disability" (Brian).

Ian and Trevor, however, explained that they made the effort to keep their daily care needs and sexual intimacy separate.

Ian: I think that, with a disability as severe as mine, it is impossible for my care needs not to influence that part of my life in some way. I have always tried to keep the two separate, and will continue to endeavor to do so, but they both involve a physical intimacy that is reflected in one another.

Trevor: My care needs do not in any way dominate my sexuality, but they do influence.

While sexuality and disability were separate entities for some participants: "I have always tried to keep the two separate, and will continue to endeavor to do so" (Ian), others felt differently: “...when I starting meeting sexual partners. It was at that point that I truly understood the impact of my disability” (Alex). Ultimately all participants found strategies in order to harmonize their care needs with their sexual needs.

\subsubsection{Harmonizing Care Needs and Sexual Needs}

As indicated by participant data the intersection between disability and sexuality involved privately managing the need for sexual intimacy with the need for daily care. Participant's highlighted; 1) the difficulty they faced in the process of harmonizing their care needs and sexual needs (Overstreet, 2008) and 2) the importance of physically preparing oneself for sexual activities (Tepper, 2000). For example, Brian's experiences with sexuality and living with a disability exemplify the difficulty some participants faced in the process of harmonizing their care needs and sexual needs.

Brian: I feel like my care needs make it a little difficult to organize for people to come over and if they were to come over I would feel nervous about asking them to help me with personal care needs. It's not really negative but it is a factor.

Brian indicated that he found it confronting to ask a potential sexual partner to help him with his care needs: "I would feel nervous about asking them to help me with personal care needs." Alex, Trevor and John found that dealing with their care needs prior to or exterior of sexual activities was beneficial.

Alex: I try as much as I can to keep my major needs (toileting, redressing, eating) separate from my sexual encounters.

Trevor: I am incontinent and therefore require assistance with toileting before any sexual act is to take place.

John: I always make sure that my attendant has thoroughly cleaned me, and that all of my care needs are taken care of prior to any act.

Harmonizing one's perceived care needs and sexual needs was important to participants. For instance, Mary and Leah's experiences with their boyfriend's exemplify the importance of being physically prepared for sexual intimacy.

Mary: Most of the time we stick to a routine because I worry about being too tired to do what I need to do in any given week so I'm probably not spontaneous enough but I do try to be more spontaneous and then there is the matter of always meeting each other at the right moment. Because sometimes when I'm ready he'll look at me and go "not now". I end up saying "are you kidding me?"

Leah: I normally try and actually do every hip stretch I know before I-otherwise I just get him to massage my hips while I'm there and as long as I don't end up crouching backwards. Sometimes I go to get off and I can't because one hip locks up. So it's like "tip me that way" [LAUGHS]. 
Through preparation participants were able to dichotomize the realities of impairment and the experiences of sexuality. In doing so, participants used planned: "I always make sure that my attendant has thoroughly cleaned me, and that all of my care needs are taken care of prior to any act" (John), "I normally try and actually do every hip stretch I know before" (Leah), in order to experience their sexuality satisfactorily. In addition to the private reconciliation of disability and sexuality and harmonizing one's care needs and sexual needs respondents explained that being accepting of oneself was a key component of their experiences with disability and sexual identity.

\subsubsection{The Importance of Accepting Oneself}

In describing the relationship between disability and sexuality participants explained that being accepting of oneself was important to constructing a positive perception of their sexuality (Murphy, Molnar \& Lankasky, 2000).

Alex: I always knew that I was "different" from other kids my age. And hey, that's fine.

John: That's the only part [his penis] of that region that works consistently. The legs don't work. Off and on I don't feel the feet properly. So I make the best use of it as I can.

Mary: Well that's actually advice that my German friend gave me. "You need to walk around naked more." So, okay, I started to do that and I felt, "this feels strange," but you know, if you don't actually look at your body enough you're going to be more uncomfortable with it or showing it to anybody else.

In the process of accepting oneself participants appeared to feel more comfortable and positive about the role disability played in the formation of their sexual identity (Esmail et al., 2010). In doing so, participants created perceptions about how they as potential sexual partners were perceived by others.

\subsection{Perceptions of Sexual Desirability}

Participants' perception of their own sexual desirability was influenced by what they thought were sexually desirable traits in conjunction with what they perceived others thought of them. Two sub-themes were apparent: Perceptions of Sexually Desirable Traits and Privatizations of Others' Perceptions (see Figure 2).

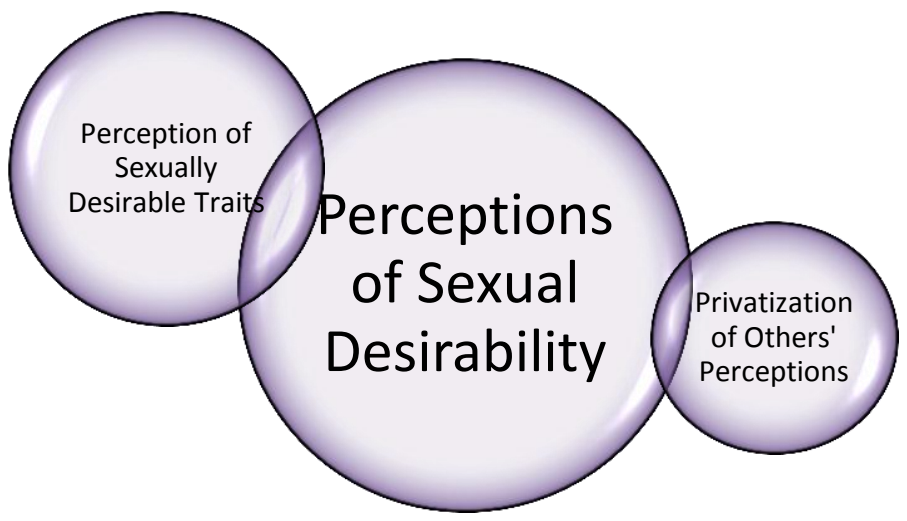

Figure 2. Perceptions of Sexual Desirability Theme and Sub-themes

\subsubsection{Perceptions of Sexually Desirable Traits}

Participants' private perceptions of sexually desirable traits within themselves and others influenced the private construction of their sexuality. Private perceptions of sexuality are characterized by individual though processes about their sexuality and sexual concepts (Simon \& Gagnon, 2003). Private perceptions of sexual desirability overlap with both interactional and public conceptualizations of sexual desirability. In this regard, participants explained that personality traits (i.e., confidence, humor and intelligence) were what made them (and others) sexually desirable (Kaufman, Kozbelt, Bromley \& Miller, 2008). They also believed that engaging in sexual activity reinforced private perceptions of one's sexual desirability (Glass \& Padrone, 1978). In terms of personality traits, participants described sexually desirable traits they perceived within themselves and others.

Alex: I think confidence is extremely attractive, which is funny because I don't feel like I exhibit enough confidence. I think that a sense of humour is also very important to sexual attractiveness. I think that my crass, bold, honest sense of humour has the potential to make me sexually attractive. 
Leah: I think I can be funny, you know, in a sarcastic kind of way.

Trevor: In my opinion, my sexiest attribute is my sense of humor and intelligence. I am a firm believer that the brain is the sexiest organ in the body, which works out well for me.

Mary: I also think that my intelligence and openness lend themselves to my sexual desirability. My sense of humor also helps in this regard.

Ian: The most obvious sexually desirable quality to me is confidence. If someone can own their body, be comfortable in it and be comfortable in expressing it - that leads to sexual desirability. I do not think that there is one physical or social quality that is universally sexually desirable. But all of these qualities, if encased in social and physical confidence, become a lot more attractive.

Alex, Leah and Trevor and Ian indicated that character and personality traits are of particular importance to the perception of sexual desirability. For instance confidence was described as an expression of comfort ability with oneself and was therefore attractive: "The most obvious sexually desirable quality to me is confidence. If someone can own their body, be comfortable in it and be comfortable in expressing it - that leads to sexual desirability" (Ian). Participants perceived humour as a sexually desirable, perhaps as a derivative of intellectualism: "In my opinion, my sexiest attribute is my sense of humor and intelligence" (Trevor). Participants also described intelligence as an important character trait: "I also think that my intelligence and openness lend themselves to my sexual desirability" (Mary), "I am a firm believer that the brain is the sexiest organ in the body, which works out well for me" (Trevor). For Brian he felt sexually desirable when he was engaged in sexual activity.

Brian: My body is sexy when I do cum...my abdominals when I cum, they tense. Can't think of anything else. I dunno. My eyes.

Participants generally believed that they had personality, character and some physical traits which they perceived as sexually desirable. Privatizations about how people with cerebral palsy thought was sexually desirable traits was further mediated by what they thought other thought of them.

\subsubsection{Privatizations of Others' Perceptions}

On the one hand, participants indicated that they mostly felt that they were sexually attractive. On the other hand, they explained that privatizations of others perceptions of their sexual desirability: 1) created tension within the private construction of their sexuality (Murray\& Harrison, 2004) and, 2) made them feel that others did not or could not find them sexually attractive (Rintala et al., 1997). For instance, Alex described the contention between privately feeling sexually desirable and privatizing the idea that others view him as sexually desirable:

Alex: Perhaps, my sense of humour and my sense of self and masculinity make me sexy. Partners have told me I have great eyes, and I am a good kisser. In all honesty, I don't feel as though I am sexually desirable. I think this stems from me feeling like my disability makes me an outsider.

For Brian, being perceived by others as a sexual being let alone a potential sexual partner was difficult to consolidate.

Brian: I don't think they see me like that [as sexual].

Investigator: How about the people in your sexual history?

Brian: They might have felt alright, that I was sexual I guess.

Investigator: What do you think they thought about your sexuality?

Brian: I think that they felt I was a sexual person and that I gave them sexual pleasure.

Investigator: Do you think they think about you as a sexual being.

Brian: For sure yeah.

Investigator: Do you think strangers would think of you as a sexual person?

Brian: No, I don't think so. No.

Alex, Ian and Leah's responses also seem to reiterate that others perceptions of their sexuality has an impact on their private sense of sexual desirability.

Alex: Most of the time I don't feel desirable in this manner. This may also be a result of social ostracism due to my disability - and the projection of attitudes surrounding disability back on to me.

Ian: Well to be perfectly honest I would be surprised if anybody does.

Leah: I think it's a social thing. Because if you went around saying to everyone "of course I'm sexy, why wouldn't I be?" I think some of it is that you would get some negative feedback so if part of me thinks I'm 
sexy it's the part of me I'm going to keep to myself because you don't let people at everything that feeds your soul.

Participants' responses seemed to indicate a struggle to reconcile how they thought about themselves: "My sense of humour and my sense of self and masculinity make me sexy" (Alex) and how they believed other perceived them: "In all honesty, I don 't feel as though I am sexually desirable" (Alex). John's experience with his former carer is an example of what he thought versus what actually happened.

John: It didn't occur to me, I mean I knew we were close. But there again, you're making me realize I constructed this purely as a carer relationship. And to be honest I was quite thrilled when suddenly I had her on my lap and here I was and here she was and suddenly there was a kiss. And OH DEAR [participant's emphasis], it was wonderful!

John further observed that the likelihood of experiencing his sexuality in the way he did with his former carer was rare because he had privatized the idea that disability excluded him as a viable sexual option for others.

John: I'm realistic enough to know that nobody who's anything like that will probably take one look at me and think...I mean the reality I think is that, a high proportion of people with disabilities will probably not get married because I mean again people who have had no experience of disability will find it very confronting. Equally I expect that these people will find the question of marriage with someone like me or even co-habitation very confronting. Because I mean there are some confronting things that I have to have done of a very personal nature, and that's just care issues.

As mentioned under both interactional and public sexual schema perceptions by others may encourage feelings of sexual undesirability within people with physical disabilities (Murray\& Harrison, 2004): "I'm realistic enough to know that nobody who's anything like that will probably take one look at me" (John). As such, participants believed that others did not find them attractive which was also consistent with the internalization of the public myth of disability and asexuality: "I mean the reality I think is that, a high proportion of people with disabilities will probably not get married because I mean again people who have had no experience of disability will find it very confronting" (John). While several private, interactional and public sexual schema influence constructions of participant sexuality many of these scripts were tied to their private construction of their body.

\subsection{Body Esteem}

Participants had some negative perceptions of their body image, but this did not necessarily have a significant impact on the construction of their sexuality. Four participants felt positively about their body image, two felt negatively and one was concerned mostly about how their body and their perception of it influenced how they experienced and constructed their sexuality. Body Esteem then, was divided into three sub-themes (see Figure 3); Positive Body Esteem, Negative Body Esteem and Bodily Experiences.

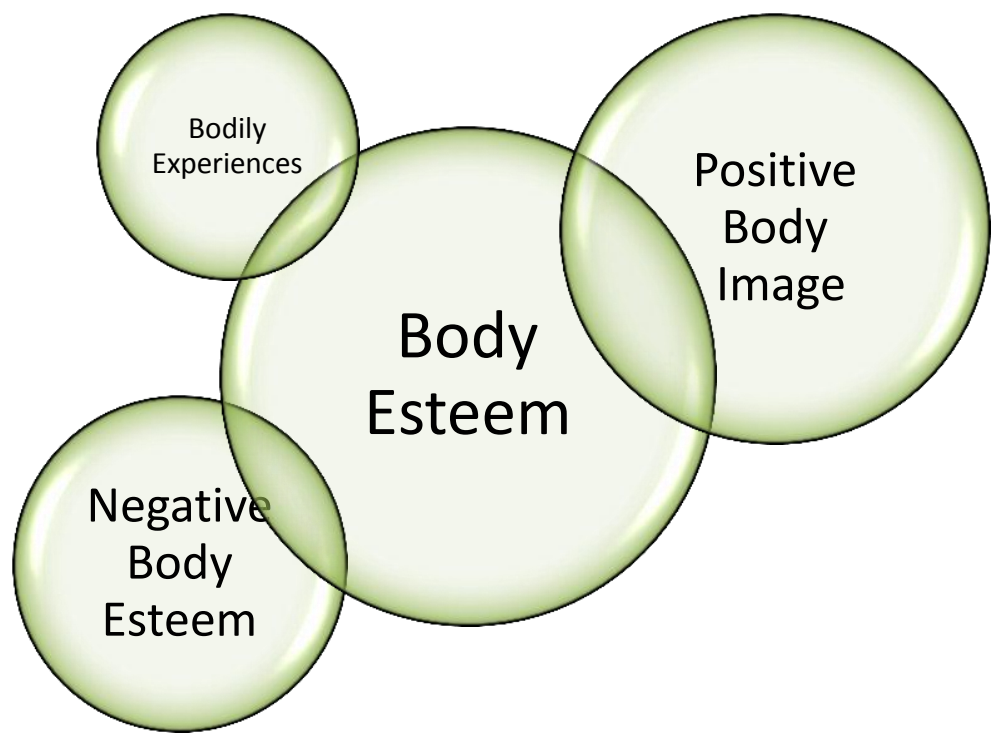

Figure 3. Body Esteem Theme and Sub-Themes

\subsubsection{Positive Body Esteem}

Body esteem (one's perception of their body image: Taylor \& Davis, 2007) had an impact on how participants 
conceptualized themselves as potential sexual partners. Notably, participants experienced positive body esteem through: 1) the private consolidation of positive sexual experiences with others (Palombi \& Mundt, 2006), 2) the process of downward social comparison (Varsamis \& Agaliotis, 2011) and 3), exploring one's sexuality (Mona, Cameron, Goldwaser, Miller, Syme \& Fraley, 2009). Leah, for instance, described how positive body esteem was privately consolidated through positive sexual experiences with her boyfriend.

Leah: I just ... I didn't think it hurt and hurt and I wasn't concerned at all about being naked in front of him or what my legs may or may not do. I think it did cross my mind afterwards. But I thought "Oh he'd tell me if things weren't going to work."

For Leah, sexual activity with her boyfriend reinforced that she wasn't worried about her body: "I wasn't concerned at all about being naked in front of him or what my legs may or may not do," and did not have to be unless her boyfriend indicated that there was a problem; "I thought 'Oh he'd tell me if things weren't going to work." For Ian, positive body esteem was also reinforced by engaging in sexual activities with others.

Ian: Good really. I think I'm sexy in those times [sexual activity with others]. I like how it [his body] moves and reacts when I'm having sex.

Positive body esteem was also validated by the process of downward social comparison. Brian articulated that he felt good about his body because it could do more than other bodies with impairments could do.

Investigator: How do you feel about your body?

Brian: Alright really. Yeah!

Investigator: Good or bad - alright.

Brian: On the good side! I could be doing better but I'm doing okay.

Investigator: Why do you feel you have a good body?

Brian: Well I can transfer and like for instance May [not real name] she can't even stand without help.

Investigator: You do archery and other sports as well. Does that make you feel like you have a good body?

Brian: Yeah and I go to the gym twice a week and do weights.

Investigator: Do you feel that doing things with your body, I mean being able to do things with your body makes you feel good?

Brian: Yes definitely. I can do more than most people in my position. So my body is good.

Exploring one's sexuality was also described as a means by which people with cerebral palsy could foster positive body esteem. Trevor described that being able to explore his sexuality instigated a positive change in his privatizations about his body.

Trevor: I have never really seen my body as sexy, but I've recently began to explore that side of my sexuality more. I am not there yet, but I'm definitely starting to change my view.

Trevor's experience with sexual exploration highlights the contention between feelings of negativity towards one's body and positive ideations of one's body.

\subsubsection{Negative Body Esteem}

Two of the participants suggested that negative body esteem in people with Cerebral Palsy is linked to privatizations of the socio-sexual implications of physical impairment (Taleporos \& McCabe, 2005). For instance, Alex indicated that negative body esteem influenced the way he privatized interactional sexual relationships.

Alex: I enjoy casual sex because I hate labels, or perhaps because I fear that I will never meet someone who wants to have a long-lasting relationship because of how my disability makes me look, so I hide behind casual sex to protect myself from getting hurt.

For Alex, negative body esteem reinforced privatizations that he was not an eligible candidate for long term sexual relationships with others: "I will never meet someone who wants to have a long-lasting relationship because of how my disability makes me look." John's thoughts, however, indicated that physical impairment on a more medicalized level reduced his ability to perceive his body positively.

John: My vulnerabilities to illness, my inability to take care of myself in some very intimate ways and rolling on from that the necessity for me to rely on others to do some rather intimate and rather messy things for me. Which most people don't have to ask another to do unless they are very elderly or very frail or very aged. Probably not wonderful, let me put it this way, what I would like to see in terms of public 
policy and medical policy is a greater emphasis on the actual sort of medical things that actually cure and replace and restore. Some will say that makes me akin to a eugenist and if some people want to make that argument. Go ahead! If you are going to find a legitimate one of these people like Bono who want to end hunger, who want to end AIDS and make it history. Why don't you add one more to the list?

All participants were of the view that people with moderate to severe cerebral palsy are often defined by what their bodies can or cannot do. For instance, John observed: "My vulnerabilities to illness, my inability to take care of myself in some very intimate ways and rolling on from that the necessity for me to rely on others to do some rather intimate and rather messy things for me." The privatization of this sentiment is influenced by both interactional (i.e., peer acceptance of impairment and/or disability) and public schema (i.e., expectations of normative movement and functioning). As such, how people with moderate to severe cerebral palsy experience their sexuality invariably involves how they relate to their bodies.

\subsubsection{Bodily Experiences}

Body esteem in individuals with moderate to severe cerebral palsy is often influenced by how much control they feel they have over their bodies (Wiegerink, Roebroeck, Donkervoort, Cohen-Kettenis \& Stam, 2008). Mary, for example, explained how her experience with impairment and her body influenced her body esteem.

Mary: I think part of - for me, with having CP is you don't always feel at one with your body because you feel like it's running its own race and you're not quite in control of it so that's one of the important things for me. I was having this conversation with my masseur this week, I go once a month, and he fixes quite a lot and I said to him 'I have this great few days, sometimes even a week after I've had a massage where I just feel totally in myself'. It's a feeling I don't get much. Like yesterday I got up and I knew I was really tired this week. I slept about 12 hours on Friday night and I thought yesterday, should I go for a walk in the morning, and I didn't feel my legs were quite with me and I ended up going for a walk at about 4 o'clock in the afternoon and I felt much better. But sometimes it's not doing what I want.

As described above Mary sometimes felt that her body was its own entity which she could not control: "sometimes it's not doing what I want." In this respect, people with moderate to severe Cerebral Palsy (versus physically typical individuals) have a unique relationship with their bodies based on their developmental history (i.e., the medicalization of their bodies). As such, sexual agency for people with Cerebral Palsy may be affected due to the privatization that they are not agents of their own bodies and therefore may not feel like agents of their own sexuality.

\subsection{Sexual Agency}

Three participants indicated that their ability to be sexually agential was impeded by feelings of apprehension. While this may have been the case some of the participants made a concerted effort to foster sexual agency within their lives through practice and positive thinking. Although five of the seven participants knew how they could initiate sexual relationships, two participants felt that there was no point investing energy into sexual pursuits as they felt that misconceptions (held by others) about disability and sexuality made it too difficult. Participant descriptions of their sense of sexual agency fell into three sub-themes (see figure 4): Feeling Apprehensive, Fostering Agency and Resignation.

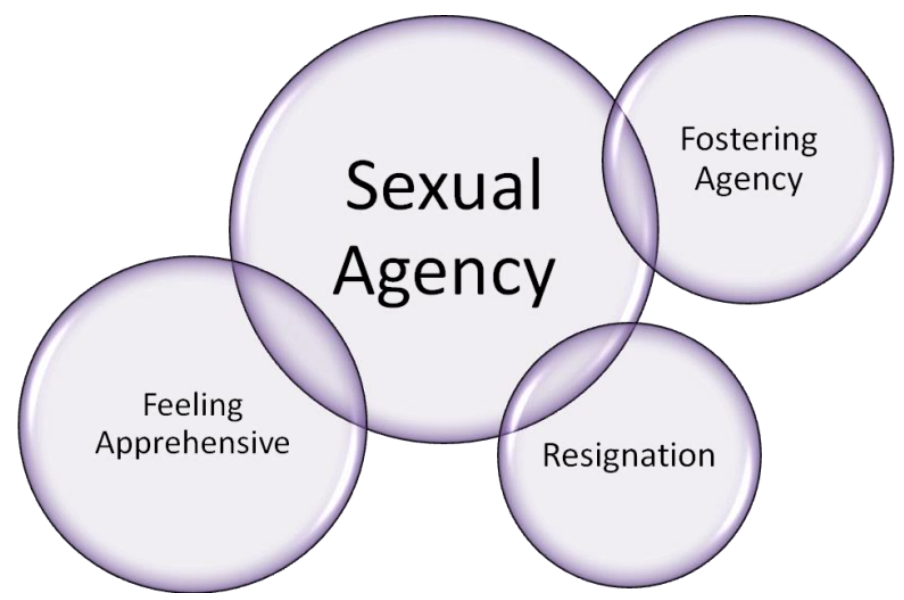

Figure 4. Sexual Agency Theme and Sub-themes

\subsubsection{Feeling Apprehensive}

Participants wereunsure about negotiating sexual relationships. They were about: 1) initiating sexual intimacy due to 
privatizations of public perceptions about people with physical disabilities and sexuality and, 2) expressing one's sexual needs (Hassouneh-Phillips \& McNeff, 2005).

In regards to privatizations about initiating sexual intimacy Brian stated:

Brian: It's hard to initiate sexual relationships. I think that I am overlooked and not necessarily considered as a sexual partner.

According to Leah and Mary their ability to be sexually agential with their boyfriends was restricted by the privatization that they could not express their sexual needs.

Leah: I was getting a lot of negative messages [from others] I think I didn't embrace it [her sexual needs]. So I think I sometimes have trouble expressing that kind of interest and then I do have trouble with my hips, which doesn't affect me most of the time, but you know, if you want to have sex it's going to become an issue.

Mary: Most of the time it is my boyfriend [who initiates sexual activity] because I'm not — I think that comes back to I'm not having, you know-because that issue about when you acknowledge your sexuality and let yourself do things. Because I didn't do that. I think I stunted myself in some ways.

Here Leah and Mary explain that although they wanted to express their sexual needs to others they were apprehensive due to negative messages from others. For instance, Leah: "I was getting a lot of negative messages I think I didn't embrace it [her sexual needs]" and not having had the opportunity to acknowledge their own sexuality: "that issue about when you acknowledge your sexuality and let yourself do things" (Mary). Although Leah did not always feel confident about enforcing her sexual agency she indicated that she needed to release some of her inhibitions in order to assert her agency.

Leah: Probably just being less inhibited though I don't realize at the time that I was being inhibited or goodness knows what I'm thinking about but ... yeah, just having a bit more confidence.

Some participants appeared to struggle with allowing themselves to practice their sexual agency due to pressures to conform to interpersonal or public sexual expectations. In contrast, others made a concerted effort to do so.

\subsubsection{Fostering Agency}

While some participants were apprehensive about enforcing their sexual agency they also made an effort to privately reject those fears. Notably, participants fostered their sense of sexual agency through practice (Wilkerson, 2002). Mary expressed that she had been apprehensive about refusing suitors who she thought were socially and sexually incompatible; although, she was glad she had not given in to her desire to conform.

Mary: Yeah, because the stigma was there already because I lived on the campus for the first couple of years I was here so even in college all the people there, they start to talk about the people who don't fit in and don't do things. And there was a lot of talk and it did play on my mind a bit, but I always thought about it in terms of meeting someone, not 'picking up'. I ditched a couple of guys at my door a couple of times and that made the rumour-mill worse but I always thought to myself, "well, in the end I'm glad I did that."

Mary highlights the interactional and public sexual expectations which may make people with Cerebral Palsy apprehensive about enforcing their sexual agency in an effort to seem typical amongst their peers regardless of the private ramifications: "Yeah, because the stigma was there already because I lived on the campus for the first couple of years I was here so even in college all the people there, they start to talk about the people who don't fit in and don't do things." She also expressed a sense of relief and empowerment via her refusal to conform to normative sexual expectations: "I ditched a couple of guys at my door a couple of times and that made the rumour-mill worse but I always thought to myself, 'well, in the end I'm glad I did that.",

For Trevor part of his journey of sexual development involved being more sexually agential in order to fulfill his desire to experience life in the way he wanted.

Trevor: I have always been willing to put myself out there, another reason that my sexuality has grown. My upbringing and surroundings also play a role, in that I was always taught to go for what I wanted, and to actively explore the world around me.

Alex expressed that the only factor that limited his sexual agency was physical mobility.

Alex: I suppose I am sexually liberated. I am reserved only by what it is that I can do physically (mobility).

Four of the participants expressed that sexual agency (i.e., initiating sexual intimacy, refusing sexual intimacy and/or 
expressing sexual needs) although something that was difficult to enforce, could help them experience their sexuality in the ways they wanted to. A few participants, however, felt that there was nothing they could do to improve how they privately constructed or experienced their sexuality.

\subsubsection{Resignation}

Some participants expressed that their sexuality could not be improved and had privately resigned to experiencing their sexuality based on what others allowed them (Due, 1995). For instance, Alex and John described their sexuality as unsatisfying and dead-ended.

Alex: I now don't often equate sex with romance. As much as I have tried to do that in the past, and sometimes currently, I feel that it is not realistic... so now, I take what I can get. I am not happy this way, but I understand it to be the reality of my sexuality.

John: I think it's the way people think about disability. So sometimes I reckon "why bother?" You know. And I don't always feel like we know what we're doing. It's hard to present myself because I don't match up. I feel exposed. I've laid out all my cards and I can't hide. I worry sometimes that the other person would react negatively.

For these participants resignation was a way to deal with negative perceptions about disability and sexuality.

\subsection{Sexual Esteem}

The information from participant transcripts indicated that sexual esteem (one's sense of self as a sexual being or potential sexual partner) had relatively little influence on how they constructed their own sexuality. However, some participants indicated that overall they did not feel quite comfortable with the idea that they could be perceived as a potential sexual partner, sexual being or sexually desirable. As such, they appear to count themselves out (see Figure 5).

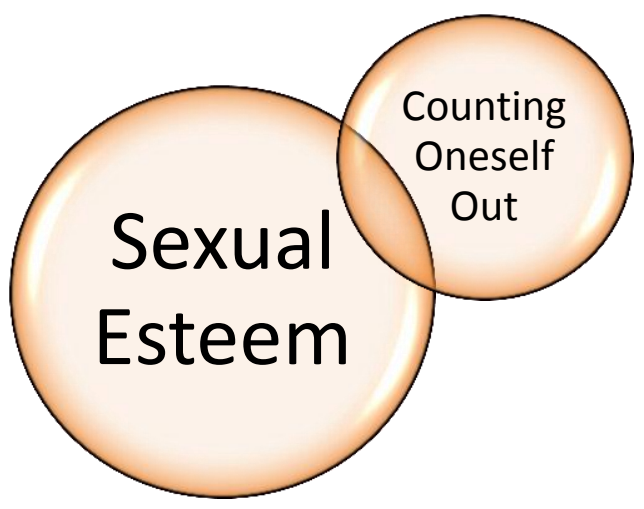

Figure 5.Sexual Esteem Theme and Sub-themes

\subsubsection{Counting Oneself Out}

"Counting oneself out" sexually was characterized within participants' responses as the private conviction that others could not perceive them as suitable sexual partners (Esmail et al., 2010). Paradoxically, participant's responses from earlier in the chapter indicated that they have positive ideations, experiences and constructions of their sexuality and yet their sexual esteem waned (Guildin, 2000). Leah, for instance indicated that she could not attribute the word "sexy" to herself:

Leah: Yeah, see sexy is not an adjective I would attribute to myself.

Ian felt that the possibility of a sexual relationship with someone was somewhat theoretical but was at best an impractical privatization:

Ian: Well I mean I guess you're aware that it's possible [finding a sexual partner]. But I mean the other issue is well, where and with whom would that be possible? I don't know whether you repress it or ignore it.

For Ian, the idea of finding a sexual partner was something he implicitly repressed or ignored: "I don't know whether you repress it or ignore it." On the other hand, John actively created distance between himself and potential sexual partners.

John: I've pretty much always kept a very discreet distanceas I think I said to you last time there have 
been the odd regret in that I spoke to this women on one or two occasions. Just a casual "hello" you know, passing of the day. I never really indicated the interest beyond that because I was too frightened to. The other part of it was that she appeared to have quite any number or reasonably of other suitors. To the effect that I didn't see myself being, a contender in a "month of Sundays." I mean, many people will be to a degree standoffish because they won't know how to handle me. They won't know whether to speak to me or not. Or they'll just step around the issues like "it's a bit too complex for me to work out." For them they just don't know what is going to happen, what I'm going to say, whether I'm going to bite them or start foaming at the mouth.

In this respect, John provides an example of the implications of sexual esteem on privatizations of oneself as a potential sexual partner: "To the effect that I didn't see myself being, a contender in a 'month of Sundays, "” sexual equal: "They won't know whether to speak to me or not," or sexually desirable: "For them they just don't know what is going to happen, what I'm going to say, whether I'm going to bite them or start foaming at the mouth." As indicated through participant responses, however, the sexuality that people with Cerebral Palsy experience (or want to experience) may not be validated or reinforced by interactional, public or private sexual schema. As such, opportunities to reconstruct normative sexual expectations and scripts are restricted. In this regard sexual schema like that of sexual spontaneity can serve as an example of the conflicting nature of hegemonic sexual schema and constructions of one's own sexuality.

\section{Limitations}

This study had some limitations; 1) cultural homogeneity, 2) restrictions of qualitative methodology, and 3) constraints of script theory. First, the cultural frame was homogenous. Namely all the participants in this study were Caucasian, from developed nations, had completed post-secondary education and were within the spectrum of middle class socio-economic status. As such, the participants of this study may only represent a range and depth of socio-sexual development experienced by members of privileged ethnic groups and resourced nations. Limited cultural and linguistic diversity (CALD) (Rao, Warburton \& Bartlett, 2006) may have skewed the findings. For instance, CALD within the present study may have made intersecting experiences of oppression more salient or it may have been identified as a sub-schema under public or interactional sexual schema. However, without information from CALD respondents the findings may lack cross-cultural utility. In addition, socioeconomic status may have a significant effect on socio-sexual agency and independence for people with Cerebral Palsy. For instance, people with significant disabilities with financial means may have more flexibility or autonomy in the provision of their health care than those who do not (Schillmeier, 2007). Financial means may also support independent living, social opportunities and sexual development. Research which includes a more culturally, ethnically and financially diverse sample is needed in order to determine whether these points of diversify would have an impact on the findings of this study.

Second, the qualitative methodology used within this study allowed for rich descriptive and contextual information. Interpretive inquiry allows for some data contours to be emphasized more than others (Mayoux, 2006). For instance, the data collected is mediated by the investigator's ability to ask questions or probe answers which allowed respondent's to comprehensively articulate their concepts, conceptualizations and conceptions of sexuality with disability. In doing so respondents may have found it easier to express some or certain sexual schema and not others due to their abstract nature or convolutions within the questions. While the in-depth interview technique used within the study provided insight about the meanings people with Cerebral Palsy give to their sexual lives a more ethnographic approach may have been beneficial. For example, if the investigator had spent more time with the participants in a non-interview environment they may have gained addition access to contextual information which may have been useful in the interpretation of participant data (Shuttleworth, 2000). This addition of contextual information may have alleviated the issue of convoluted questions or abstract articulations of sexual phenomena. Research which explores constructions of sexuality with Cerebral Palsy using different qualitative techniques (i.e., focus groups, case studies and observations) would further clarify the findings of this study.

Finally, sexual script theory was the theoretical basis for this research. Sexual script theory however, delineates sexual influences into public, interactional and private sexual schema. The results from the present inquiry indicate that public, interactional and private sexual schema are interdependent in their effect on constructions of sexuality with cerebral palsy. Interdependence of theoretical constructs introduces interdeterminancy (Dworkin 1985). This is to say that sexuality as constructed by people with Cerebral Palsy cannot be dissected and explained within the confines of public, interactional or private sexual schema. The findings of this study emphasize that people with cerebral palsy are agents in the construction of their sexuality. Bandura's social cognitive theory $(1986,1997,2006)$, which highlights people as social agents, may therefore be a better theory to apply to constructions of sexuality with cerebral palsy. Research which employs Bandura's social cognitive theory and constructions of sexual with disability would be beneficial to further understanding agency and sexuality with disability. 


\section{Conclusion}

This study sought to explore, understand and to develop existing knowledge and theory on how people with cerebral palsy constructed their sexuality. Bringing to the fore discussions on both sexual agency and being, this study found that constructions of sexuality with cerebral palsy are primarily influenced by interactional sexual schema. It also highlights the role of sexual participation through sexual exploration. This study has demonstrated - through the utilization of sexual script theory - the complexity of individual constructions of sexuality with cerebral palsy.

This portion of the study found that constructions of sexuality are partly created through private mental processes which involve inner dialogue (Emerson, 1983). It highlights that people with impairment may reconcile disability with sexuality primarily by dealing with disability and sexuality separately. For example Tepper (2000), who is an individual with a disability, considered sexuality and disability as very different concepts. Participants perceived the harmonizing of care needs with sexual needs as imperative to satisfactorily experiencing sexuality. Harmonizing care needs with sexual needs was characterized by attending to physical care needs (i.e., bath, toilet or eat) before sexual encounters (see also Murphy, Molnar \& Lankasky, 2000).

Accepting oneself. Accepting oneself was important to people with cerebral palsy's sense of sexuality. Murphy, Molnar and Lankasky (2000) observed that adults with cerebral palsy who accepted themselves with a disability are more comfortable with their sexuality. By critically discounting exclusionary or negative sexual schema, people with cerebral palsy learn to be more accepting of their abilities and attribute positive conceptualizations to themselves and their sexual identity. Participants considered personal resources such as confidence, humour and intelligence to make them sexually desirable to others. This could be because engaging in intellectually stimulating interactional relationships added to one's sense of personal attractiveness. Kaufman et al. (2008) observed that people who are perceived by others as having a good sense of humour were likely to have more friends and social opportunities than their peers. Nonetheless, some people with cerebral palsy perceive their personality attributes to be overshadowed by physical attributes in how they are perceived by others.

Body esteem. Participants had mixed perceptions of body esteem as an aspect of their sexuality. Downward social comparisons were associated with positive body esteem. For instance, participants believed that other people with severe physical disabilities (i.e., paralytic spinal cord injuries, or degenerative musculoskeletal conditions) may be more physically, socially and sexually restricted by their bodies than they were.

Negative body esteem could be an after effect of the lack of resources to support people with cerebral palsy in their sexual participation (i.e., sexual surrogates, workers, sexual facilitation from care providers, privacy or accessibility to transport) (see Earle, 1999). By implication, people with cerebral palsy may perceive their bodies as socially and sexually contentious.

Sexual agency.Participants believed their sexual agency was constrained. For instance, they were apprehensive about explicitly asking for what they required from a sexual partner for fear that they may seem overly demanding, which could frustrate a sexual partner or end a relationship. This apprehension could decrease sexual satisfaction, sense of sexual empowerment or expose people with cerebral palsy to increased risk of abuse. For instance, Hassouneh-Phillips and McNeff (2005) reported that women with significant impairment could be less assertive with partners and make relationship choices which exposed them to abuse. The present study suggests that people with cerebral palsy do in fact recognize that being sexually agential would increase their sense of sexual satisfaction and empowerment.

Participants believed that sexual agency could be enhanced with personal effort. Guildin (2000) explained that while it may be difficult to change physical characteristics or levels of functionality it may be within an individual's control to dictate how they will behave while negotiating and/or engaging in sexual activities. Wilkerson's (2002) research indicated that people who are socially and sexually marginalized can bolster their sense of sexual agency through practice. For instance, some participants reported refusing suitors who they did not perceive compatible. In doing so, they felt empowered and confident about their choices as sexual beings. Research should explore aspects in which sexual agency may be realized relatively more than others.

Although the findings from this study can be used to inform further estimations about individual sexuality, they initiate important discussions around the theoretical and practical implications sexual agency with disability. Primarily, sexual theory needs to be more cognizant of sexual agency as primary in the construction of sexuality with significant disability. In addition, healthcare providers and people with cerebral palsy must work as partners in sexual health in order to support positive and agentic constructions of sexuality with significant disability. As many scholars have already noted, it seems as though the private sphere of sexuality and disability has yet to fully reap the benefits of societal change towards issues of inclusion, acceptance and education about disability. 


\section{References}

Abbott, S. (2010). Resistant bodies: Claims to liberation and desire at the intersections of crip and queer. Middletown: Wesleyan University.

Bandura, A. (1986). Social foundations of thought and action: A social cognitive theory. Englewood Cliffs: Prentice-Hall.

Bandura, A. (1997). Self-efficacy: The exercise of control. New York: 1997.

Bandura, A. (2006). Guide for constructing self-efficacy scales. In F. Pajares, \& T. C. Urdan, Self-efficacy beliefs of adolescents (pp. 307-338). Charlotte: Information Age Publishing.

Blakar, R. M., \& Nafstad, H. E. (2006).Towards a definition of communication encompassing ethical dimensions.In R. Keeble, Communication Ethics Today (pp. 177-186). Leicester: Troubador Publishing Ltd.

Cheng, M. M., \& Udry, J. R. (2002).Sexual behaviors of physically disabled adolescents in the United States.Journal of Adolescent Health, 31(1), 48-58.http://dx.doi.org/10.1016/S1054-139X(01)00400-1

Due, T. (1995). Disabled face special challenges in dating. Houston Chronicle, May 24, p. 5D

Dworkin, R. A. (1985). "Why Should Liberals Care about Equality" in A Matter of Principle. Cambridge: Harvard University Press.

Earle, S. (1999). Facilitated sex and the concept of sexual need: disabled students and their personal assistants. Disability and Society, 14, 309-323.http://dx.doi.org/10.1080/09687599926163

Emerson, C. (1983). The outer word and inner speech: Bakhtin, Vygotsky, and the internalization of language. Critical Inquiry, 10(2), 245-264. http://dx.doi.org/10.1086/448245

Esmail, S., Darry, K., Walter, A., \& Knupp, H. (2010). Attitudes and perceptions towards disability and sexuality. Disability and Rehabilitation, 32(14), 1148-1155. http://dx.doi.org/10.3109/09638280903419277

Falkman, K. W., Sandberg, A. D., \& Hjelmquist, E. (2005). Theory of mind in children with severe speech and physical impairment (SSPI): A longitudinal study. International Journal of Disability Development and Education, 52(2), 139-157. http://dx.doi.org/10.1080/10349120500086397

Froyum, C. M. (2010). Making 'good girls': sexual agency in the sexuality education of low-income black girls. Culture, Health and Sexuality, 12(1), 59-72. http://dx.doi.org/10.1080/13691050903272583

Giddens, A. (1991). Modernity and self-identity: Self and society in the late modern age. Palo Alto: Stanford University Press.

Glass, D. D., \& Padrone, F. J. (1978).Sexual adjustment in the handicapped. Journal of Rehabilitation, 44(1), 43-47.

Gould, J. (2009). There is more to communication than tongue placement and 'show and tell': Discussing communication from a speech pathology perspective. Australian Journal of Linguistics, 29(1), 59-73. http://dx.doi.org/10.1080/07268600802516384

Grogan, S. (2008). Body image: Understanding body dissatisfaction in men, women, and children. London: Taylor \& Francis.

Guildin, A. (2000). Self-claiming sexuality: Mobility impaired people and American culture. Sexuality and Disability, $18(4), 233-238$.

Hassouneh-Phillips, D., \& McNeff, E. (2005). "I thought I was less worthy": Low sexual and body esteem and increased vulnerability to intimate partner abuse in women with physical disabilities. Sexuality and Disability, 23(4), 227-240. http://dx.doi.org/10.1007/s11195-005-8930-3

Jemtå, L., Fugl-Meyer, K. S., \& Öberg, K. (2008). On intimacy, sexual activities and exposure to sexual abuse among children and adolescents with mobility impairment. Acta Pediatrica, 97(5), 641-646. http://dx.doi.org/10.1111/j.1651-2227.2008.00757.x

Kant, I. (1958). Critique of Pure Reason.London: Macmillan.

Kaufman, M. (2010). The Ultimate Guide to Sex and Disability: For All of Us Who Live With Disabilities, Chronic Pain, and Illness: Easy Read Large Edition. Readhowyouwant.

Kaufman, S. B., Kozbelt, A., Bromley, M. L., \& Miller, G. L. (2008). The role of creativity and humor in human mate selection. Yale University Press: New Haven.

Kolotkin, R. L., Binks, M., Crosby, R. D., Østbye, T., Gress, R. E., \& Adams, T. D. (2006). Obesity and sexual quality 
of life. Obesity, 14(3), 472-479. http://dx.doi.org/10.1038/oby.2006.62

Lease, S. H., Cohen, J. E., \& Dahlbeck, D. T. (2007). Body and sexual esteem as mediators of the physical disability-interpersonal competencies relation. Rehabilitation Psychology, 52(4), 399-408. http://dx.doi.org/10.1037/0090-5550.52.4.399

Mayoux, L. (2006). Quantitative, qualitative or participatory? which method, for what and when. In V. Desai, \& R. B. Potter, Doing development research (pp. 113-129). London: Sage.

McCormack, J., McLeod, S., McAllister, L., \& Harrision, L. (2010). My speech problem, your listening problem, and my Frustration: The experience of living with childhood speech impairment. Language, Speech, and Hearing Services in Schools, 41(4), 379-392. http://dx.doi.org/10.1044/0161-1461(2009/08-0129)

Moin, V., Duvdevany, I., \& Mazor, D. (2009). Sexual identity, body image and life satisfaction among women with and without physical disability. Sexuality and Disability, 27(2), 83-95. http://dx.doi.org/10.1007/s11195-009-9112-5

Mona, L. R., Cameron, R. P., Goldwaser, G., Miller, A. R., Syme, M. L., \& Fraley, S. S. (2009). Prescription for pleasure: Exploring sex-positive approaches in women with spinal cord injury. Topics in Spinal Cord Injury Rehabilitation, 15(1), 15-28. http://dx.doi.org/10.1310/sci1501-15

Morris, J. (1991). Pride against Prejudice.London: Women's Press.

Murphy, K. P., Molnar, G. E., \& Lankasky, K. (2000).Employment and social issues in adults with cerebral palsy. Archives of Physical Medicine and Rehabilitation, 81(6), 807-811. http://dx.doi.org/10.1053/apmr.2000.6798

Murray, C. D., \& Harrison, B. (2004). The meaning and experience of being a stroke survivor: An interpretative phenomenological analysis. Disability and Rehabilitation, 26(13), 808-816. http://dx.doi.org/10.1080/09638280410001696746

Overstreet, L. C. (2008). Splitting sexuality and disability: A content analysis and case study of internet pornography featuring a female wheelchair user. Sociology Theses. Paper 22.

Palombi, B. J., \& Mundt, A. M. (2006). Achieving Social Justice for College Women With Disabilities. In R. Toporek, Handbook for social justice in counseling psychology: Leadership, vision and action (pp. 170-184). London: Sage.

Parker, R. G. (2007).Sexuality, health, and human rights. American Journal of Public Health, 97(6), 972-973. http://dx.doi.org/10.2105/AJPH.2007.113365

Phillips, M. J. (1990). Damaged goods: Oral narratives of the experience of disability in American culture. Social Science and Medicine, 30(8), 849-857. http://dx.doi.org/10.1016/0277-9536(90)90212-B

Piotrowski, K., \& Snell, L. (2007). Health needs of women with disabilities across the lifespan. Journal of Obstetric, Gynecologic \& Neonatal Nursing, 36(1), 79-87. http://dx.doi.org/10.1111/j.1552-6909.2006.00120.x

Quinlan, M., \& Bates, B. (2008). Dances and discourses of (dis)ability: Heather Mills' embodiment of disability on Dancing with the Stars. Text and Performance Quarterly, 28(1-2), 64-80. http://dx.doi.org/10.1080/10462930701754325

Rao, D. V., Warburton, J., \& Bartlett, H. (2006). Health and social needs of older Australians from culturally and linguistically diverse backgrounds: issues and implications. Australasian Journal on Ageing, 25(4), 174-179. http://dx.doi.org/10.1111/j.1741-6612.2006.00181.x

Rintala, D. H., Howland, C. A., Nosek, M. A., Bennett, J. L., Young, M. E., Foley, C. C., et al. (1997). Dating issues for women with physical disabilities. Sexuality and Disabiltiy, 15(4), 219-242.

Rurangirwaa, J., Van Naarden Braun, K., Schendel, D., \& Yeargin-Allsopp, M. (2006). Healthy behaviours and lifestyles in young adults with a history of developmental disabilities. Research in Developmental Disabilities, 27(4), 381-399. http://dx.doi.org/10.1016/j.ridd.2005.01.003

Schillmeier, M. (2007). Dis/abling spaces of calculation: blindness and money in everyday life. Environment and Planning D., 25, 594-609. http://dx.doi.org/10.1068/d4173

Shakespeare, T. (1996). Disability, identity and difference.In G. M. Colin Barnes, Exploring the Divide (pp. 94 -113). Leeds: The Disability Press.

Shields, N., Murdoch, A., Loy, Y., Dodd, K. J., \& Taylor, N. F. (2006). A systematic review of the self-concept of children with cerebral palsy compared with children without disability. Developmental Medicine and Child Neurology, 48(2), 151-157. http://dx.doi.org/10.1017/S0012162206000326

Shuttleworth, R. P. (2000). The search for sexual intimacy for men with cerebral palsy.Sexuality and Disability, 18(4), 
263-282.

Simon, W., \& Gagnon, J. H. (1986). Sexual scripts: Permanence and change. Archives of Sexual Behaviours, 15(2), 97-120. http://dx.doi.org/10.1007/BF01542219

Simon, W., \& Gagnon, J. H. (1987). A sexual scripts approach.In J. H. Geer, \& W. T. O'Donohue, Theories of human sexuality (pp. 363-383). London: Plenum Press.

Simon, W., \& Gagnon, J. H. (2003). Sexual scripts: Origins, influences and changes. Qualitative Sociology, 26(4), 491-497. http://dx.doi.org/10.1023/B:QUAS.0000005053.99846.e5

Taleporos, G., \& McCabe, M. (2002).The impact of sexual esteem, body esteem, and sexual satisfaction on psychological well-being in people with physical disability. Sexuality and Disabiltiy, 20, 177-183.

Taleporos, G., \& McCabe, M. (2005).The relationship between the severity and duration of physical disability and body esteem. Psychology and Health, 20(5), 637-650. http://dx.doi.org/10.1080/0887044042000334733

Taylor, B., \& Davis, S. (2007). The extended PLISSIT model for addressing the sexual wellbeing of individuals with an acquired disability or chronic illness. Sexuality and Disability, 25(3), 135-139. http://dx.doi.org/10.1007/s11195-007-9044-x

Tepper, M. S. (2000). Sexuality and disability: The missing discourse of pleasure. Sexuality and Disability, 18(4), 283-290.

Varsamis, P., \& Agaliotis, I. (2011). Profiles of self-concept, goal orientation, and self-regulation in students with physical, intellectual, and multiple disabilities: Implications for instructional support. Research in Developmental Disabilities, 32(5), 1548 -1555. http://dx.doi.org/10.1016/j.ridd.2011.01.054

Weeks, J. (1977). Coming out: Homosexual politics in Britain from the nineteenth century to the present. London: Quartet Books Ltd.

Wiegerink, D. J., Roebroeck, M. E., Donkervoort, M., Cohen-Kettenis, P. T., \& Stam, H. J. (2008). Social, intimate and sexual relationships of adolescents with cerebral palsy Compared with Able-Bodied Age-Mates. Journal of Rehabilitation Medicine, 40(2), 112-118. http://dx.doi.org/10.2340/16501977-0137

Wilkerson, A. L. (2002). Disability, sex radicalism, and political agency. NWSA Journal, 14(3), 33-57. http://dx.doi.org/10.2979/NWS.2002.14.3.33

World Health Organization. (2011). Disabilities. Retrieved February 18th, 2011, from http://www.who.int/topics/disabilities/en/

\section{$(\mathrm{cc}) \mathrm{BY}$}

This work is licensed under a Creative Commons Attribution 3.0 License. 